\title{
The Salittu Formation in southwestern Finland, part II: Picritic-basaltic volcanism in mature arc environment
}

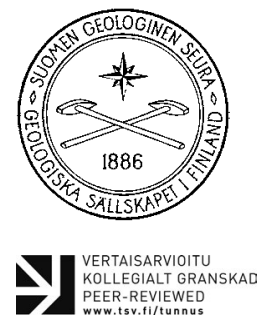

\section{Abstract}

The Salittu Formation is one of the few metavolcanic successions in the Svecofennian orogen that contain ultramafic rocks. New samples were collected from the picritic and basaltic rocks as well as spatially associated gabbroic rocks, and their major and trace element compositions are presented and discussed here. Although the metavolcanic rocks have experienced primary alteration and two metamorphic events, elements that are insensitive to alteration (rare earth elements, $\mathrm{Zr}, \mathrm{Nb}, \mathrm{Ni}$ ) have been used to infer their source and evolution. Based on the similar shapes of the rare earth element patterns in the metabasalt and metapicrite, basaltic melt derived from picritic one by fractional crystallization. The high $\mathrm{Ni}$ and $\mathrm{Mg}$ contents, $\mathrm{Ni} / \mathrm{MgO}$ and $\mathrm{Zr} / \mathrm{Nb}$ ratios, and multielement patterns make a slightly enriched garnet Iherzolite a likely source for the metapicrite. With the exception of synvolcanic gabbros within the metavolcanic rocks, the gabbroic intrusions at Salittu have no genetic link to the metavolcanic rocks.

Geochemical comparison with modern basalts suggests that the picritic and basaltic melts were generated in a mature arc environment during a rifting event. Picritic melt rose from convective mantle to the crust and formed a magma chamber. Basaltic melt fractionated in the chamber and extruded upon an earlier formed volcanic pile as basalt and synvolcanic gabbro. Soon after extrusion of the basalt, picritic melts, similar in composition to the earlier picrite, rose through the crust and extruded on top of the basalt.

Comparison with three other metapicrite occurrences in southern Finland suggests that although the occurrences may be considered broadly comagmatic, each had their specific sources and probably also tectonic environments during emplacement.

Keywords: metavolcanic rocks, gabbros, volcanism, picrites, basalts, geochemistry, Paleoproterozoic, Svecofennian Orogeny, Salittu, Finland

Author e-mail: mikko.nironen@gtk.fi / mikko.nironen@gmail.com

Editorial handling: Jussi S. Heinonen (jussi.s.heinonen@helsinki.fi) 


\section{Introduction}

Ultramafic metavolcanic rocks, with komatiites predominating over picrites, are characteristic constituents of Archean terrains whereas in Proterozoic terrains the volume of ultramafic magmatism is lower and the magmas are geochemically more fractionated (e.g. Sharkov \& Bogina, 2009). There are few well documented examples of Proterozoic picritic volcanic and subvolcanic rocks: among 2.44 Ga and ca. 2.0 Ga komatiites in the Central Lapland Greenstone Belt in northern Finland (Hanski et al., 2001); as ferropicritic lavas and dikes in the ca. 2.0 Ga Pechenga belt in northwestern Russia (Hanski, 1992; Hanski et al., 1990; Hanski \& Smolkin 1995); as lavas in the 1.9-1.8 Ga Svecofennian orogen (Makkonen, 1996; Bergström, 1997; Väisänen \& Mänttäri, 2002; this study); as dikes in the 1.88 Ga Cape Smith belt, Canada (Mungall, 2007); and among the $1.11 \mathrm{Ga}$ Keneewanan basaltic volcanic and subvolcanic rocks of North America (Sutcliffe, 1987; Klewin \& Shirley, 1992).

Ultramafic metavolcanic rocks are scarce in the Svecofennian orogen. They have scattered occurrence among sedimentary rocks in southern Finland (Kousa, 1985; Peltonen, 1995; Makkonen, 1996; Barnes et al., 2009), and in the Skellefte district of northern Sweden (Malå group; Bergström, 1997; Berge, 2013). The ultramafic metavolcanic rocks of the Salittu Formation in the Orijärvi area, southwestern Finland (Fig. 1) is among the few documented examples, and possibly volumetrically the largest ultramafic volcanic rock in the Svecofennian orogen. The ultramafic rocks of the Salittu Formation were first described by Eskola (1914) who considered them to be magmatic peridotite, whereas Mikkola (1950) reinterpreted the rocks to be of metamorphic origin. Schreurs et al. (1986) were the first to interpret the rocks as metavolcanic, mainly based on breccia- and pillow-like structures in the ultramafic rocks and their association with pillow basalts. They presented the mineral chemical as well as major and minor element geochemical characteristics, and suggested an oceanic island arc type setting during emplacement of the rocks. Väisänen and Mänttäri (2002) divided the rocks in the Orijärvi area into four formations of which the Salittu Formation is the youngest. They presented the elemental geochemical characteristics of each formation and discussed the possible tectonic settings of the formations: the chemistry of the lowermost Orijärvi formation resembles modern subduction-related environments; the overlying Kisko formation shows evolved arc-type chemistry; and the Toija and Salittu formations, the latter with E-MORBtype chemistry, were interpreted to have formed in a back-arc or intra-arc rift.

The area of the Salittu Formation was remapped during this study, and an interpretation of structural evolution as well as stratigraphy and duration of volcanism are given in a companion paper (Nironen et al., 2016). In this paper complete elemental geochemistry of the metavolcanic rocks of the Salittu Formation is presented, with the aim to determine the petrogenesis of the picritic-basaltic volcanism as well as tectonic setting of emplacement.

\section{Geological setting}

The Orijärvi area is part of the roughly E-W trending Uusimaa Belt, consisting of felsic to mafic volcanic rocks and sedimentary rocks. Ultramafic rocks are minor in volume: the picritic rocks of the Salittu Formation occur mainly at Salittu and scatteredly farther east, forming a discontinuous belt of at least $30 \mathrm{~km}$ length. The rocks were subject to early Svecofennian (1.90-1.87 Ga) magmatism and metamorphism, involving medium to high grade metamorphism and emplacement of granitoid rocks and gabbros (Lahtinen et al., 2005, and references therein). The late Svecofennian $(1.84-1.79 \mathrm{Ga})$ granitic magmatism and associated high-T low-P type metamorphism overprinted the early Svecofennian metamorphism in southernmost Finland, including the Orijärvi area (Schreurs \& Westra, 1986; Skyttä \&Mänttäri, 2008). 


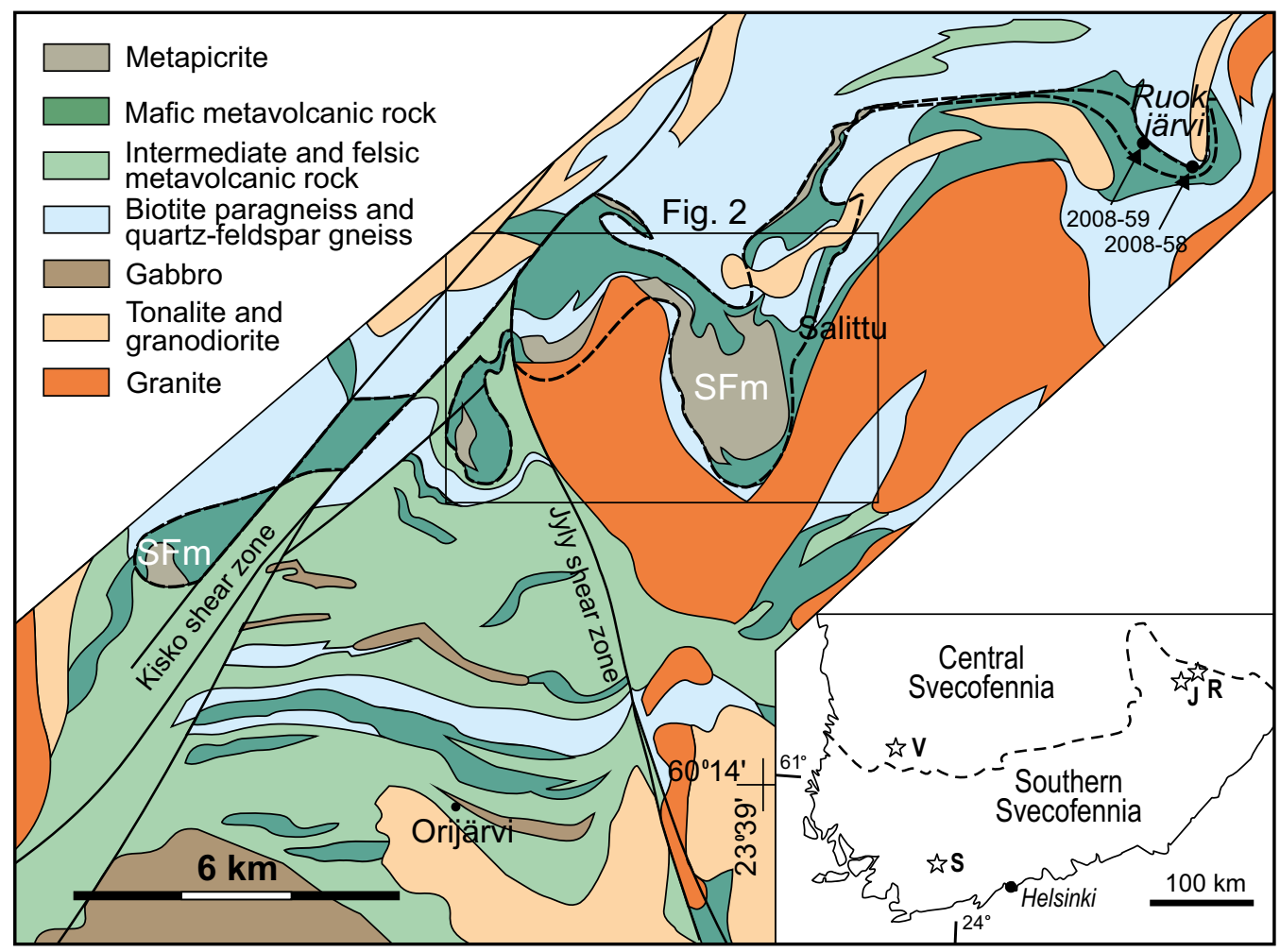

Figure 1. Geological map of the Orijärvi area, modified from Salli (1955) and Väisänen and Mänttäri (2002). Major shear zones are shown by solid black lines, the Salittu Formation (SFm) is shown by black broken line. Sites of ultramafic metavolcanic rocks in southern Finland are shown in inset: $\mathbf{S}=\mathrm{Salittu}$, $\mathrm{V}=$ Vammala, $\mathrm{J}=$ Juva, $\mathrm{R}=$ Rantasalmi.

\section{Rock types}

The picritic and basaltic metavolcanic rocks of the Salittu Formation occur as a belt with varying width (Fig. 1). The metabasalt is overlain by metapicrite, which occurs as small lenses and larger units within the metabasalt (Fig. 2a). The metapicrite can be easily recognized by its brown-green, pitted weathered surface. The rock consists of larger grains of clinopyroxene (light gray in weathered surface) and olivine (rusty brown) in a fine-grained matrix of hornblende and phlogopite. The abundance of olivine and pyroxene varies considerably (Schreurs et al., 1986). Olivine, 4-10 $\mathrm{mm}$ in diameter, occurs as anhedral grains, variously altered to serpentine. Clinopyroxene occurs as pale gray porphyroblasts with well-developed crystal faces and with diameter of 8-20 $\mathrm{mm}$; these blasts are typically less weathered than the groundmass and cause the pitted surface. In places olivine is the only megacrystic mineral and the even distribution suggests an originally porphyritic texture. The metapicrite varies from homogeneous to fragmental. The fragmental type of metapicrite contains light greenish-brown angular fragments, less weathered than the surrounding rock, that range in size from 1 to $5 \mathrm{~cm}$ (up to 20 $\mathrm{cm}$; Fig 2b). The rock probably represents an autobrecciated lava.

The metabasalt is generally banded, with dark bands consisting of green amphibole, plagioclase and diopside, alternating with lighter-colored diopside-rich bands. A breccia structure is rather common, and pillow (or pillow-like) structure occurs locally (Fig. 2c). In addition to the 


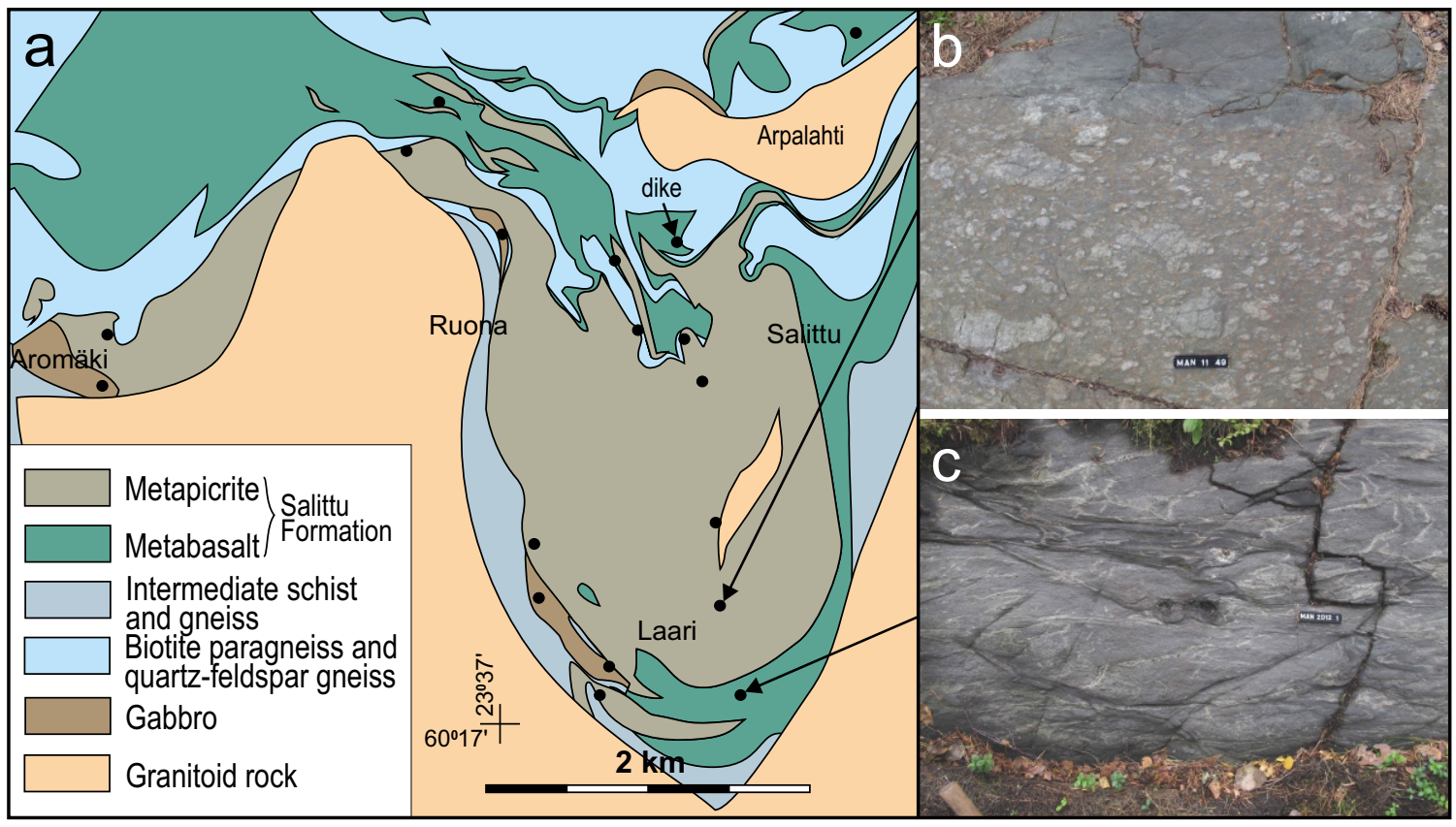

Figure 2. a) Geological map of Salittu. Sample sites are shown by black points. b) Metapicrite. Fragmental type in the lower part of the picture, homogeneous type (dike?) in the upper part. Length of code bar $12 \mathrm{~cm}$. c) Metabasalt with pillow-like structure.

metavolcanic rocks of the Salittu Formation, the supracrustal rocks at Salittu consist of andesitic schists and gneisses of probable volcanic or volcaniclastic origin as well as biotite paragneiss and quartz-feldspar gneiss; all these are crosscut by intermediate and felsic intrusive rocks.

Gabbroic bodies occurring within and adjacent to the ultramafic metavolcanic rock are variable. The gabbro at Aromäki (Fig. 2a) is unfoliated and has gradational contacts with the metavolcanic rock whereas the metavolcanic rock sharply crosscuts the foliated gabbro body at Laari. The contact relationship between the metavolcanic rock and the unfoliated, coarse-grained gabbro at Ruona is unknown. An unfoliated, fine-grained composite dike was found to sharply crosscut the foliated mafic volcanic rock (Fig. 2; see also Fig. 3a in Nironen et al. 2016). The dike contains a dark marginal phase and a lighter-colored central phase.

\section{Geochemistry}

Samples of metavolcanic rocks of the Salittu Formation as well as gabbro and dike samples were analyzed at the Labtium Oy, Finland (Table 1); four older samples (JA-98-P37, JA-98-P41, JA-98-P44, 92008781) were analyzed at the Chemical laboratory of the Geological Survey of Finland that preceded the Labtium Oy. Major elements and $\mathrm{Ba}, \mathrm{Rb}, \mathrm{Sr}, \mathrm{Zr}, \mathrm{Y}, \mathrm{S}, \mathrm{V}, \mathrm{Cu}, \mathrm{Zn}, \mathrm{Cr}$ and $\mathrm{Ni}$ were determined by XRF, and the other elements by ICP-MS. The fact that the analyses were not made as a single batch may have caused analytical bias. More detailed description of the analytical methods, precision and lowest reliable concentration is given in Rasilainen et al. (2007).

The mobile elements have been subject to secondary alteration, as seen by anomalously high $\mathrm{K}, \mathrm{Rb}$ and $\mathrm{Ba}$ contents (Table 1) but the general 


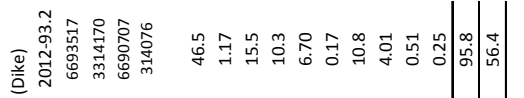

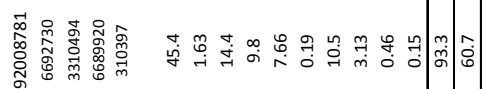

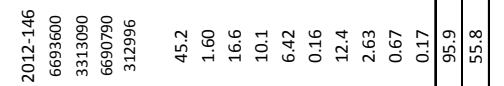

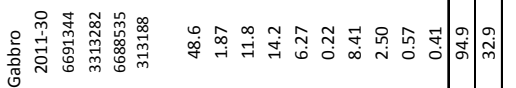

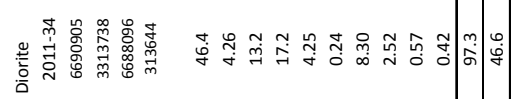

\section{minn!}

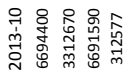

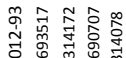

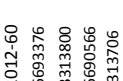

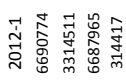

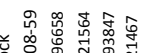

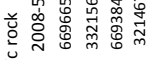

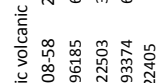

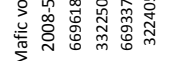

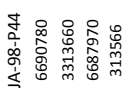

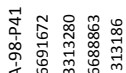

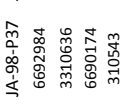

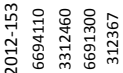

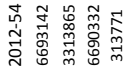

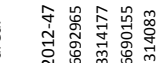

营

泫

蒙

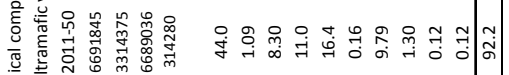

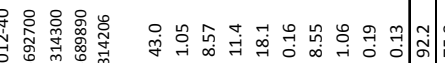

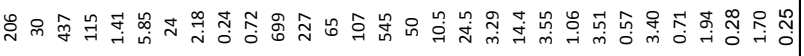

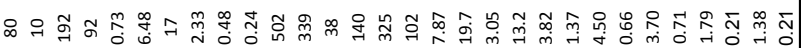

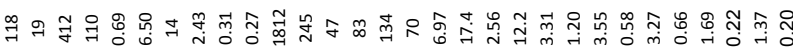

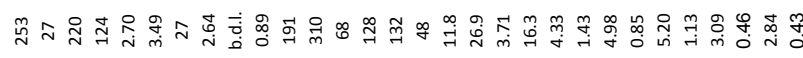

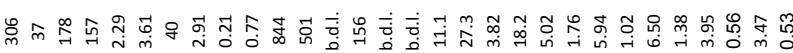

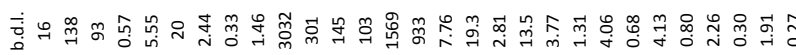

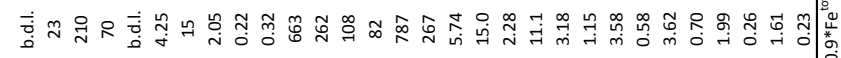

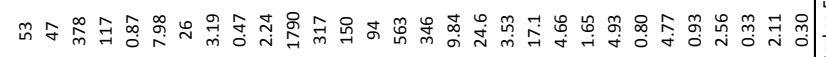

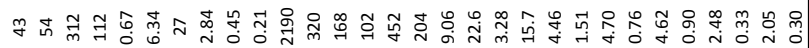

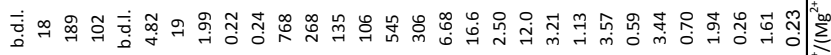

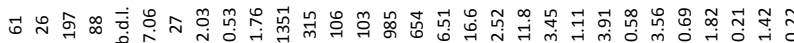

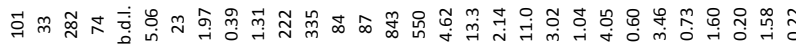

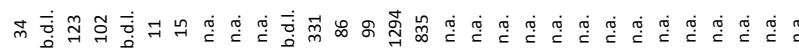

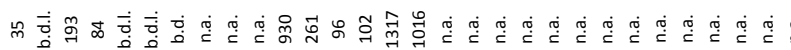

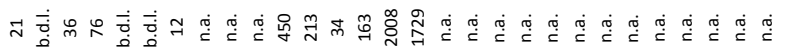

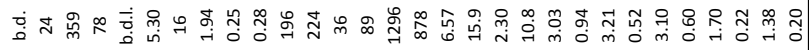

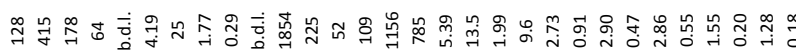

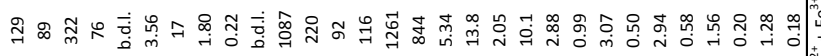

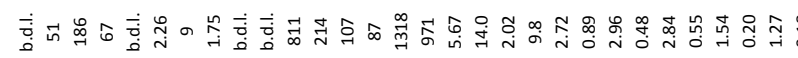

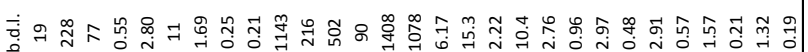

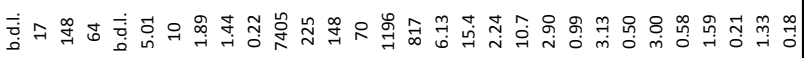

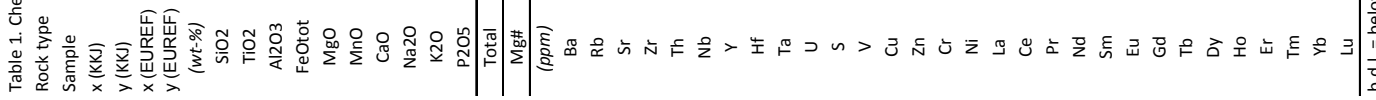



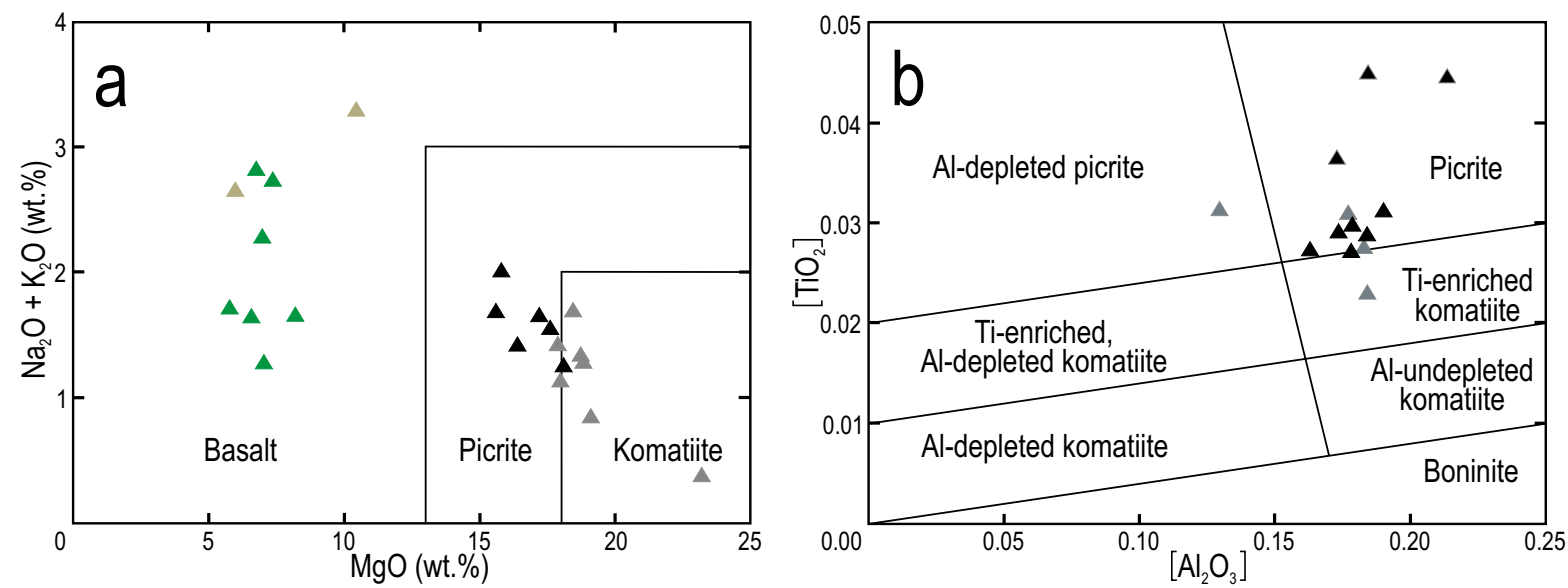

Figure 3. Analyses of volcanic rocks from the Salittu area plotted in classification diagrams. a) Total alkali vs. silica (TAS) diagram (modified after Le Bas, 2000). b) $\left[\mathrm{Al}_{2} \mathrm{O}_{3}\right]$ vs $\left[\mathrm{TiO}_{2}\right]$ diagram for high-MgO volcanic rocks (Hanski, 1992). Black triangles = ultramafic rocks of Table 1, gray triangles = samples from Väisänen and Mänttäri (2002), green triangles = mafic rocks of Table 1, olive green triangles = samples from Ruokjärvi (see Fig 1).

geochemical characteristics of the metavolcanic rocks may be determined by immobile elements. The rocks follow a subalkaline trend and the mafic volcanic rock is basaltic (Fig 3a). According to IUGS classification (Le Bas, 2000), rocks with $\mathrm{MgO}>12 \%$ and $\left(\mathrm{Na}_{2} \mathrm{O}+\mathrm{K}_{2} \mathrm{O}\right)<3 \%$ are called picrites, rocks with $\mathrm{MgO}>18 \%,\left(\mathrm{Na}_{2} \mathrm{O}+\mathrm{K}_{2} \mathrm{O}\right)$ $<2 \%$ and $\mathrm{TiO}_{2}<1 \%$ are komatiites, and rocks with $\mathrm{MgO}>18 \%,\left(\mathrm{Na}_{2} \mathrm{O}+\mathrm{K}_{2} \mathrm{O}\right)<2 \%$ and $\mathrm{TiO}_{2}$ $>1 \%$ are meimechites. With these constraints the high-MgO samples are picritic to meimechitic. They plot in the picrite and komatiite fields in the $\left(\mathrm{Na}_{2} \mathrm{O}+\mathrm{K}_{2} \mathrm{O}\right)$ versus $\mathrm{MgO}$ diagram (Fig. 3a), and in the $\left[\mathrm{TiO}_{2}\right]$ versus $\left[\mathrm{Al}_{2} \mathrm{O}_{3}\right]$ diagram of Hanski et al. (2001) they plot mainly in the picrite field (Fig. 3b).

The metavolcanic rocks display rare earth element (REE) patterns that are very similar to each other, with moderate enrichment in light REE (LREE, Fig. 4a). The REE and other incompatible element values are parallel but higher in the metabasalt than in the metapicrite, and the patterns of the samples from Ruokjärvi (olive green lines) are slightly different to those of the other metabasalt samples. This difference is assumed to it be real although the Ruokjärvi samples were analyzed separately from the other metabasalt samples. In the incompatible element diagram (Fig. 4c), the metapicrite samples display moderate to weak negative anomalies in Ta (except for one sample), $\mathrm{Ti}$ and $\mathrm{Y}$. The metabasalt samples display moderate to weak negative $\mathrm{Ta}$ and $\mathrm{Ti}$ anomalies with the exception of the two samples from Ruokjärvi which show a slightly positive Ta anomaly.

There is more scatter in the patterns of the gabbro samples: the REE pattern of the Aromäki sample (92008781) is similar to those of the metabasalt samples whereas the the Laari samples (2011-30, 2011-34) have flatter REE patterns with higher HREE concentrations (Fig. 4b). In the incompatible element diagram the other gabbro samples and the dike display negative $\mathrm{Nb}$ and $\mathrm{Ta}$ anomalies whereas in the Aromäki sample such an anomaly is not visible (Fig. 4d). The geochemical similarity suggests that the Aromäki gabbro is synvolcanic. The other gabbro bodies and the dike probably have no genetic link to the metavolcanic rocks. The dike rock is likely a conduit of an eroded gabbroic body, and implies that gabbroic magmatism occurred repeatedly in the Orijärvi area, from ca. $1875 \mathrm{Ga}$ to less than $1.82 \mathrm{Ga}$ (injection of the dike during $\mathrm{D}_{5}$ deformation; Nironen et al., 2016). 

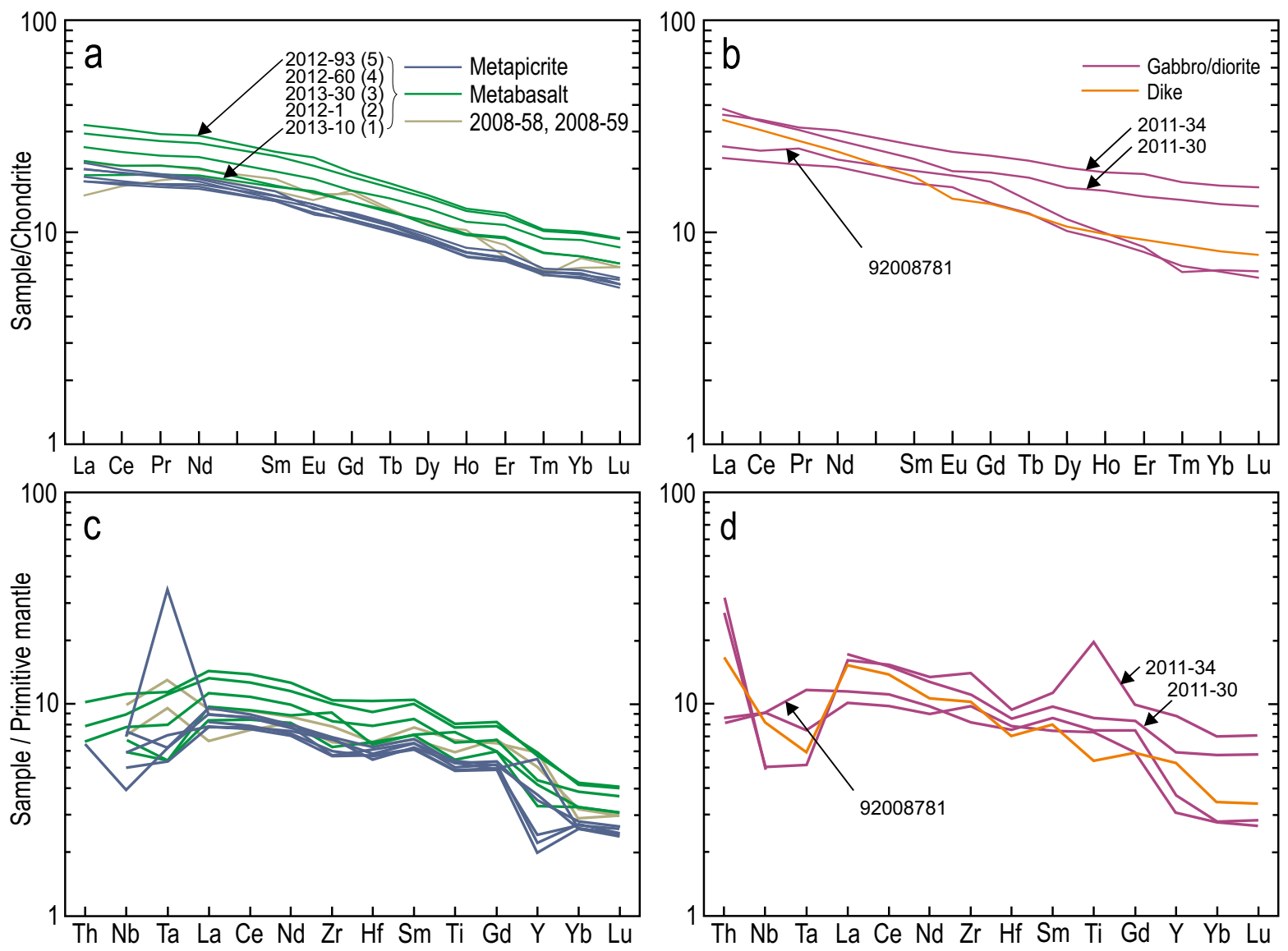

Figure 4. Chondrite-normalized REE diagram of samples from metavolcanic (a) and intrusive (b) rocks of the Salittu area. Normalizing values from Boynton (1984). Samples from Ruokjärvi marked by olive green. Assumed fractionation trend in other metabasalt samples is shown (1 to 5). Mantle-normalized incompatible element diagram of samples from metavolcanic (c) and intrusive (d) rocks. Normalizing values from Sun and McDonough (1989).

\section{Discussion}

\subsection{Geochemical and petrogenetic considerations}

Experimental phase equilibrium studies indicate that partial melting of mantle peridotite produces basaltic melts at low pressures but picritic and komatiitic melts with higher degrees of melting and at higher pressures and temperatures (Herzberg \& O’Hara, 1998). Picritic rocks have been explained to represent primitive melts from the upper mantle (Herzberg \& O'Hara, 1998), or to have formed by addition of olivine to less $\mathrm{Mg}$-rich magmas (e.g. Schuth et al., 2004). In large igneous provinces where both basaltic and picritic flows occur, basalts have been explained to have derived from picritic magma by fractionation of olivine and clinopyroxene (e.g. Zhang et al., 2006).

Below the metavolcanic rocks of Salittu are considered with respect to alteration, crustal contamination, differentiation, source, and magmatic evolution. The strong metamorphic overprint (e.g. secondary olivine), and lack of 
mineral and isotope chemistry preclude a profound petrogenetic approach but some conclusions can be made.

The high contents of fluid-mobile elements $\mathrm{K}, \mathrm{Ba}, \mathrm{Rb}$ and $\mathrm{Sr}$ in some metapicrite samples (Table 1) are probably the result of metamorphic alteration. Alteration can be seen also as relatively low total element contents, generally $90-95$ wt.\%. The variable Ta and Y contents (Fig. 4c) are more problematic because these elements should be insensitive to metamorphism. A possible explanation for the variable contents is analytical error, although the variation is seen in metapicrite samples that were analyzed in a single batch.

Studies on picrites in young environments indicate very limited contamination during transport through the crust (e.g. Woodland et al, 2002; Jennings et al., 2017). Crustal contamination tends to increase the contents of $\mathrm{K}, \mathrm{Rb}, \mathrm{Ba}$ and $\mathrm{Si}$ but in the case of the Salittu metavolcanic rocks metamorphic overprint weakens the use of these elements, and in lack of isotopes the effects of potential contamination remains unresolved.

The REE patterns of the Salittu metavolcanic rocks are very similar to each other (Fig. 4a). The similar shapes and variable concentration levels are consistent with magmatic processes, e.g. fractional crystallization of olivine and pyroxene from picritic parental magma and development of basaltic residual melt. To study further the possibility of fractional crystallization the assumed fractionation trend with increasing REE values ( 1 to 5 in Fig. 4a) were marked in selected major and minor element diagrams (Fig. 5). Fractionation of olivine would result in linear increase of $\mathrm{Si}, \mathrm{Al}, \mathrm{Ti}$ and $\mathrm{Na}$, and decrease of $\mathrm{Ni}$ and $\mathrm{Cr}$ with decreasing $\mathrm{Mg}$. Expected trends may be seen in $\mathrm{Al}$ and $\mathrm{Ni}$. In the samples marked as 1 and 5 the very low $\mathrm{SiO}_{2}$ and relatively high $\mathrm{CaO}$ values (19.2 wt.\% and 17.4 wt.\%, respectively; Table 1) are the result of primary alteration rather than regional metamorphism. When these two samples are not considered, the remaining samples (2, 3 and 4) plot close to each other, and the trends in Figure 5 are not in conflict with fractional crystallization. This example shows also that while the major element compositions changed during primary and secondary alteration, the REE remained unaffected.

Several criteria have been used in identification of primitive (primary mantle-derived) magmas, including $\mathrm{Mg}$ number $(\mathrm{Mg \#})$ that should be $>70$ for a basaltic melt derived from the least refractory mantle peridotite (e.g. Frey et al., 1978). The Mg numbers of the Salittu metapicrite are $>73$ whereas values of the metabasalt are lower, 54-62 (Table 1). Another criterion is the high concentration of compatible trace elements, especially $\mathrm{Ni}$ which is a sensitive indicator of olivine fractionation. The $\mathrm{Ni}$ contents in the metapicrite (820-1730 ppm; Fig. 5d) are much higher than 400-500 ppm estimated for primitive magmas (Wilson, 1989). Ni contents are high also in the metabasalt (200-930 ppm) compared with typical basalts (50-200 ppm; e.g. Hart \& Davis, 1978). The $\mathrm{Ni} / \mathrm{MgO}$ ratios of the metapicrite samples plot close to the line of primitive mantle ratio, and those of the metabasalt samples slightly below the line (Fig. $5 \mathrm{~d}$ ). The two samples well over the line may represent cumulate. Since the original texture in the metavolcanic rocks is largely overprinted by metamorphism, the amount of cumulus material is unknown.

Immobile elements in basaltic rocks have been used to assess whether the source of the basalts was depleted or enriched with respect to these elements relative to primitive mantle, i.e. source heterogeneity (Pearce \& Norry, 1979). The elements $\mathrm{Zr}$ and $\mathrm{Nb}$, used in Figure 6, are especially informative because the $\mathrm{Zr} / \mathrm{Nb}$ ratio is insensitive to variations in the degree of partial melting or fractional crystallization. The Salittu metapicrites plot between N-MORB and E-MORB. From Figure 6 it appears that the metapicrite samples represent primitive melts from heterogeneous convective mantle with depleted and enriched domains. Such diverse sources should be seen in the REE patterns as a spread in LREE contents, which is in conflict with the very similar REE patterns of the metapicrite samples (Fig. 4a). Following 

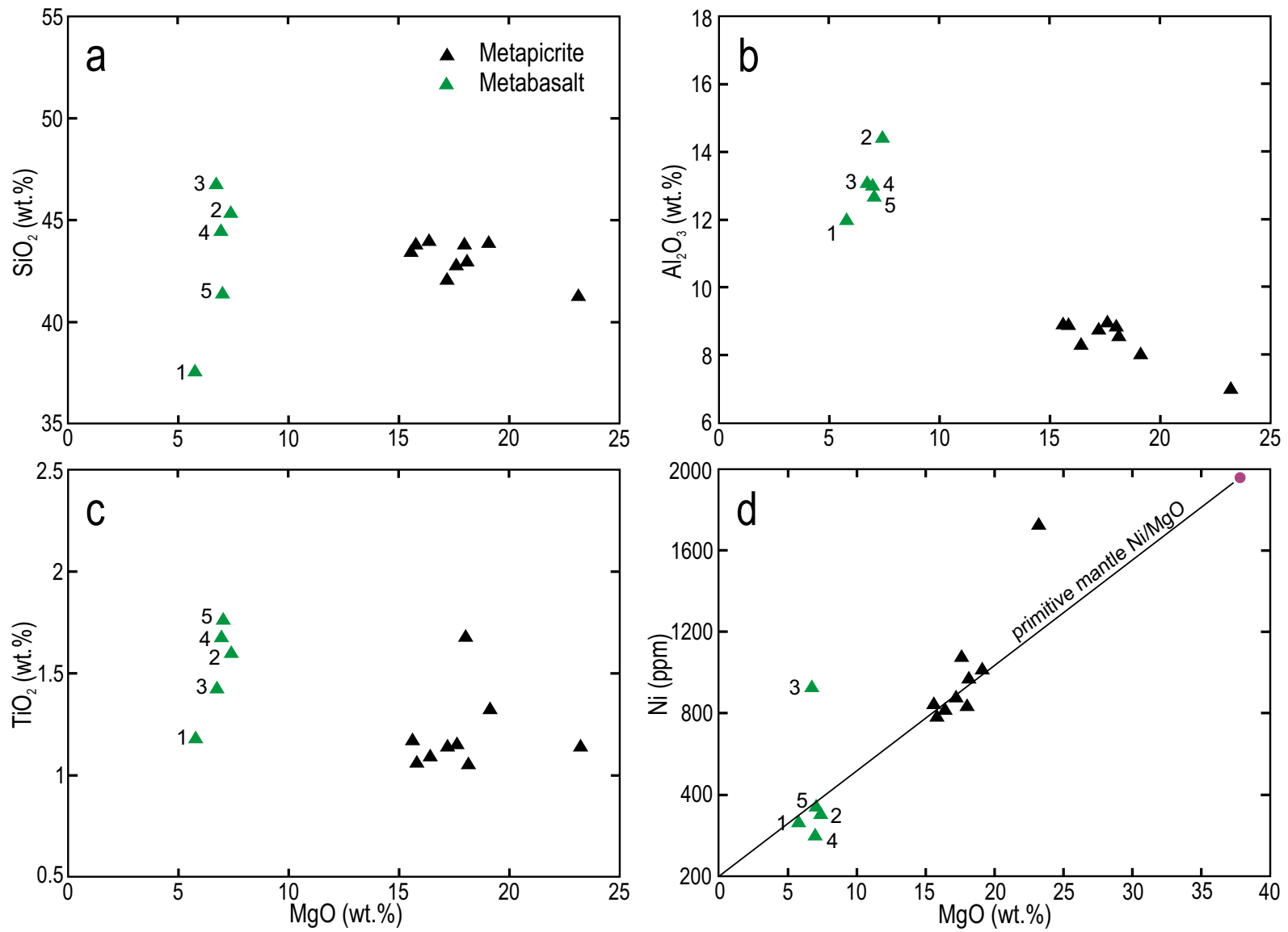

Figure 5. Variation diagrams of the Salittu metabasalt and metapicrite. The differentiation trend in basalt, interpreted from REE pattern (Fig. 4a), is shown by numbers. Samples 2008-58 and 2008-59 are excluded. Purple dot in 4d is model composition of primitive upper mantle by McDonough and Sun (1995; MgO = $37.8 \mathrm{wt} . \%, \mathrm{Ni}=1960 \mathrm{ppm}$ ) and black line is primitive mantle line with constant $\mathrm{Ni} / \mathrm{MgO}$ ratio.

the approach of Pearce (1983), the multielement pattern of the metapicrite (Fig. 4c) may be explained by a source in enriched lithosphere.

Picrites originate in deeper mantle than less magnesian basalts. Some modern, arc-related picritic melts are thought be generated within the garnet lherzolite stability field at $\geq 100 \mathrm{~km}$ depth (see Woodland et al. 2002). The HREE-depleted pattern of the Salittu metapicrite suggests garnet in the residue. Because the high $\mathrm{Ni}$ and $\mathrm{Mg}$ contents of Salittu metapicrite require olivine as the dominant mineral in the source, and the $\mathrm{Ni} / \mathrm{MgO}$ is the same as in the model primitive mantle (Fig. 5d), the most plausible source rock for the metapicrite is garnet lherzolite. Another possibilty could be garnet pyroxenite, but the low $\mathrm{Ti}$ contents relative to Fe contents in the metapicrite (cf. Heinonen \& Luttinen, 2008, Fig. 7b) makes this alternative less probable.

In Figure 6 the metabasalts plot close to the line of primitive mantle ratio. The metabasalt samples are interpreted to represent basaltic melt that formed by fractional crystallization of a primary picritic magma. Considering that the Salittu metapicrite stratigraphically overlies the metabasalt, the preferred evolution model is that 


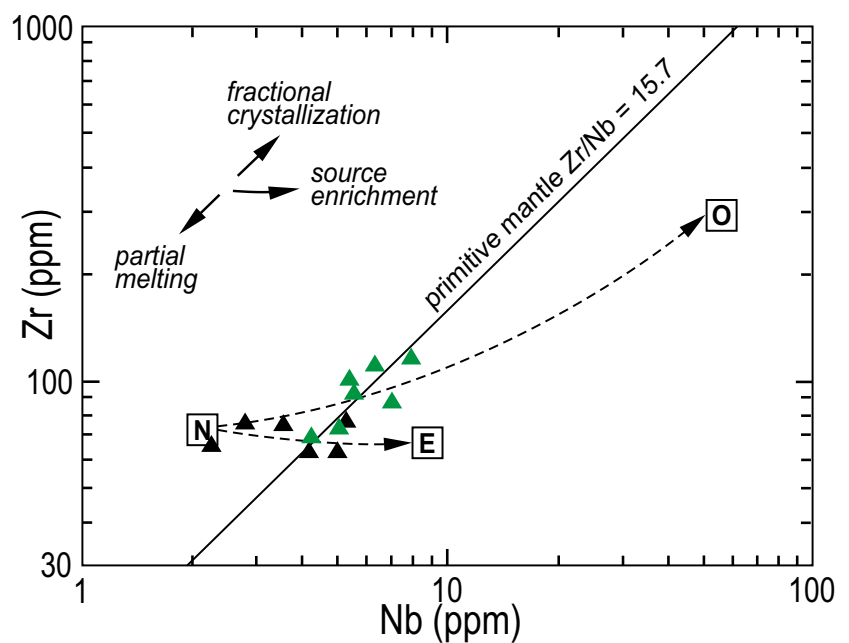

Figure 6. Zr vs. Nb diagram for assessing differentiation and source processes, applied from Peltonen et al. (1996). Black triangles = metapicrite, green triangles = metabasalt of Table 1. $\mathrm{N}=$ normal mid-ocean ridge basalt, $\mathrm{E}=$ enriched mid-ocean ridge basalt, $\mathrm{O}=$ ocean island basalt. Broken lines indicate enrichment paths. See text for further explanation. primary picritic melt rose from the convective mantle and gathered into a sill-like chamber in the crust; basaltic melt fractionated from the pictitic melt, rose to the surface and crystallized as basalt and synvolcanic gabbro; and finally primary picrite melts rose through the crust upon the basalt.

\subsection{Tectonic implications}

Picritic rocks are found among basalts in both intraplate and interplate tectonic settings. The former include large igneous provinces (e.g. Ellam \& Cox, 1991) and oceanic hot spots such as Hawaii (e,g, Ireland et al., 2009). These as well as picrites formed in continental rift environments (Larsen et al., 2003; Tsikouras et al., 2008) represent divergent settings whereas picrites formed in convergent plate margin settings such as island arcs (Rohrbach et al., 2005, and references therein; Zhang et al., 2008; Sorbadere et al., 2011) are rare. The convergent plate picrites have been explained to originate from unusually hot descending subduction slab (e.g. Eggins, 1993; Mann et al., 1998; Schuth et al., 2004), or to represent magmatism related to backarc spreading (Yamamoto, 1988).

Negative $\mathrm{Nb}, \mathrm{Ta}, \mathrm{Zr}$ and $\mathrm{Ti}$ anomalies in incompatible element diagrams of basalts are considered to be diagnostic of arc environment (subduction component; Pearce, 1983). However, also continental flood basalts may display negative $\mathrm{Nb}-\mathrm{Ta}$ anomalies and enrichment of incompatible elements if they have assimilated material from crust that has grown in subduction zone. A negative $\mathrm{Nb}$ anomaly is common in melts from rifts and continental break-up areas as well (Verma, 2006).

Based on new global datasets, Li et al. (2015) questioned the validity of binary diagrams in assessing the tectonic environment and suggested the use of mantle-normalized trace-element patterns instead. In Figure 7 a the Salittu metabasalts are compared with modern subalkaline basalts from various tectonic environments. The pattern of the Salittu metabasalts is closest to those in continental arc and island basalts although a specific environment cannot be deduced.

As a next step the REE pattern of the Salittu metapicrite was compared with REE patterns of picrites of various ages in continental and volcanic arc environments (Fig. 7b). Continental picrites tend to have higher LREE values than the arc picrites but there does not appear to be any systematic change with age. Overall, the diagram does not give clues to the tectonic environment of the Salittu metapicrite during emplacement.

Väisänen and Mänttäri (2002) noted the lack of negative $\mathrm{Nb}, \mathrm{Ta}, \mathrm{Zr}$ or Ti anomalies (in N-MORB normalized diagram) in the metavolcanic rocks of the Salittu Formation, and concluded that they 

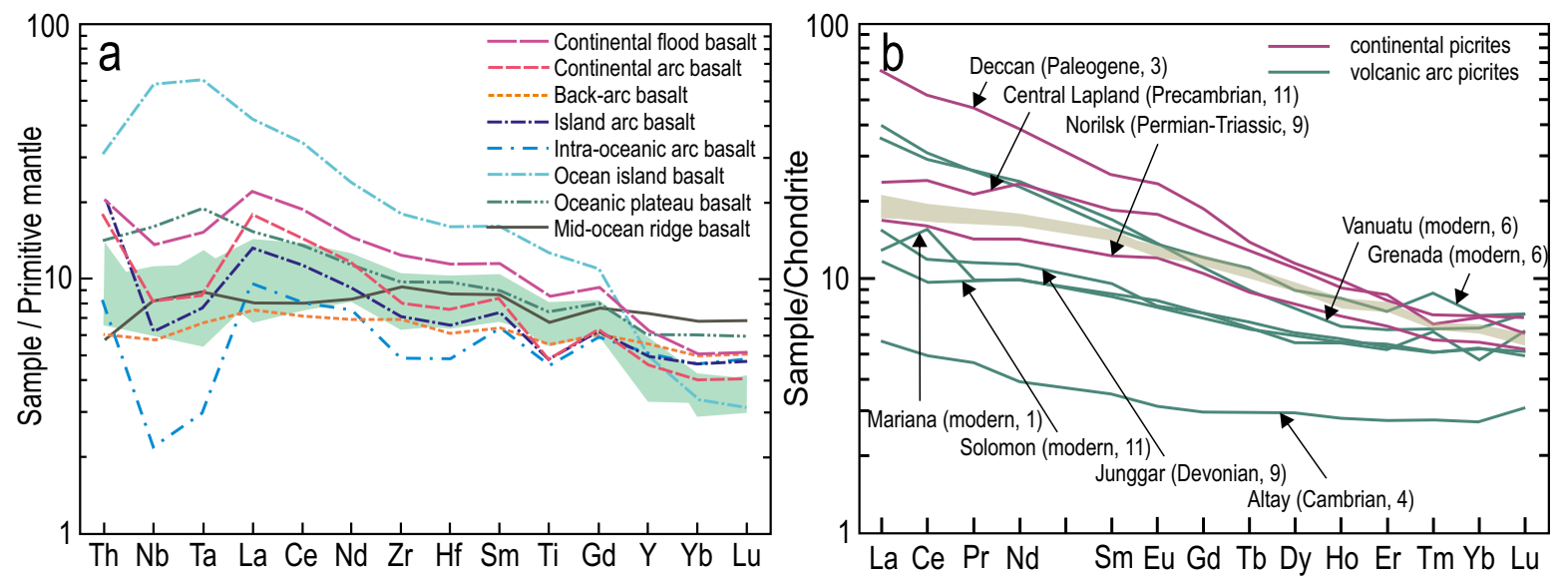

Figure 7. a) Average immobile trace element patterns of subalkaline basalts in various tectonic environments, normalized to primitive mantle (modified from Li et al., 2015). Shaded green area shows the combined pattern of the Salittu metabasalt. Primitive mantle values are from Sun and McDonough (1989). b) Average chondrite-normalized REE patterns of continental and volcanic arc picrites of various ages. Data of arc picrites from Woodland et al. (2002), Schuth et al. (2004), Kohut et al. (2006), Zhang et al. (2008), Izokh et al. (2010) and Sorbadere et al. (2011), and of continental picrites from Lightfoot et al. (1993), Hanski et al. (2001), Melluso et al. (2006) and Tsikouras et al. (2008). Numbers of analyses are shown after respective ages. Shaded brownish area shows the combined pattern of the Salittu metapicrite. Normalizing values from Boynton (1984).

show E-MORB type chemistry, consistent with Figure 6. Väisänen and Mänttäri (2002) proposed that the Salittu Formation represents rifting of the arc in a back-arc tectonic setting. The new samples (except the Ruokjärvi samples) show moderate to weak negative Ta and Ti (and possibly Y) anomalies (in mantle-normalized diagram; Fig. 4c) but as indicated above, multielement patterns are more relevant than individual element contents. According to the immobile trace element pattern (Fig. 7a), a back-arc environment is questionable.

Mantle and Collins (2008) noted that trace element patterns in modern basaltic suites steepen as the thickness of the arc increases, and they used the $\mathrm{Ce} / \mathrm{Y}$ ratio of basalts in active volcanoes of volcanic arcs to assess crustal thickness variations during orogeny. Application to the Salittu metabasalt, with $\mathrm{Ce} / \mathrm{Y}$ ratios from 0.58 to 1.00 , would correspond to $15-30 \mathrm{~km}$ crustal thickness during emplacement. Provided that Precambrian volcanic environments were essentially similar to the present ones, the $15-30 \mathrm{~km}$ thickness is compatible with emplacement of the Salittu volcanics in a mature arc environment (Nironen et al., 2016).

\subsection{Comparison to other metapicrite-metabasalt associations in southern Finland}

Barnes et al. (2009) divided the mafic and ultramafic metavolcanic rocks in the Finnish Svecofennian into several suites and concluded that despite the geographical separation and different tectonic environments the ultramafic and mafic metavolcanic rocks (including the Salittu formation) and intrusions in southern Finland are comagmatic $(1.88 \mathrm{Ga})$. In Figure $8 \mathrm{a}$ the REE patterns of the Salittu metapicrites are compared with patterns in metapicrites from other localities in southern Finland (see inset in Fig. 1). There is considerable scatter in the REE patterns of the Rantasalmi and Vammala metapicrites: for example 

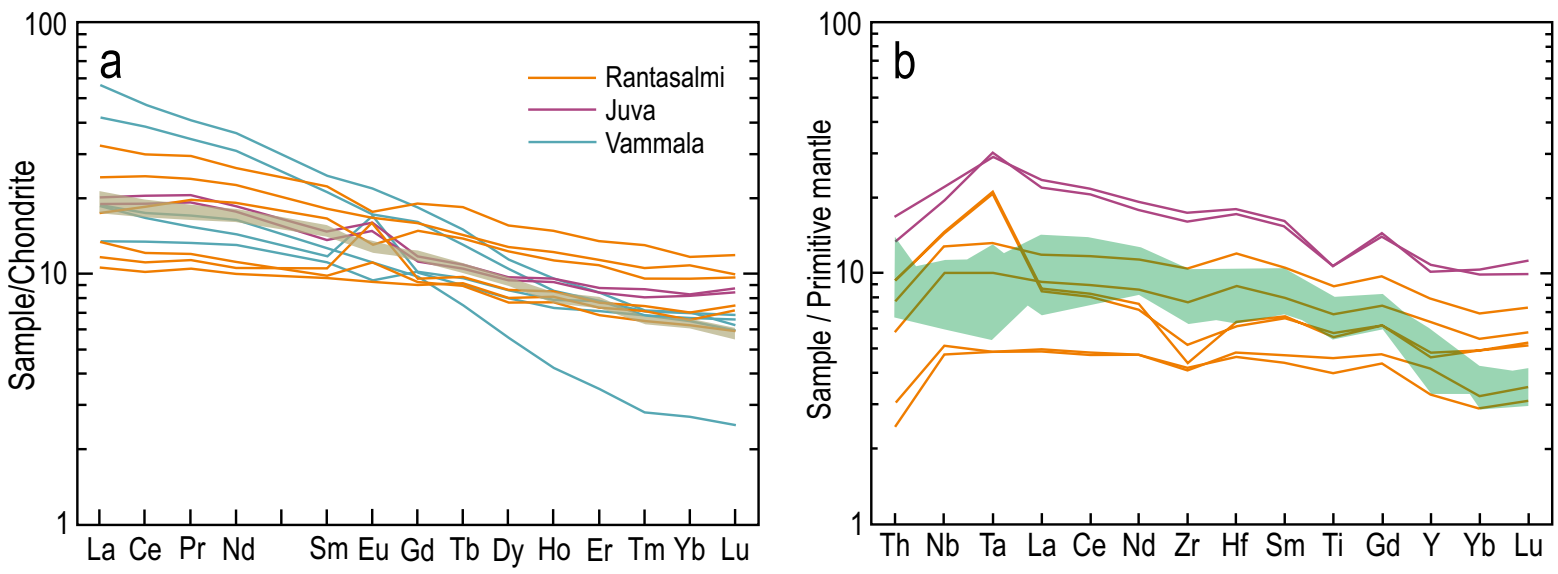

Figure 8. a) Chondrite-normalized REE diagram of metapicrite samples from the Rantasalmi, Juva and Vammala areas, Salittu samples shown as shaded area. b) Mantle-normalized incompatible element diagram of metabasalts from the Rantasalmi and Juva areas, Salittu samples shown as shades area. Data from Barnes et al. (2009).

the Rantasalmi and Vammala samples display both negative and positive $\mathrm{Eu}$ anomalies. The Salittu samples are closest to the two metapicrite samples of Juva. When the incompatible elements of metabasalts are compared (Fig. 8b), the samples from Salittu do not resemble those of either Rantasalmi or Juva (there are no metabasalts at Vammala). Based on these comparisons it appears that although the ultramafic-mafic metavolcanic rocks may be broadly considered comagmatic, there is considerable variety in their source composition and evolution in different tectonic environments. For example, Peltonen (1995) concluded that at Vammala the metapicritic rocks represent remnants of oceanic crust.

\section{Conclusions}

The mobile element variations in the metavolcanic rocks of the Salittu Formation show that these rocks passed through alteration, both primary and regional metamorphic, and therefore the possible crustal contamination is difficult to assess. However, the immobile and incompatible elements provide clues for some petrogenetic considerations. The high $\mathrm{Ni}$ and $\mathrm{Mg}$ contents in the metapicrite samples of the Salittu Formation suggest primitive magma, but based on the very similar enriched REE patterns and the $\mathrm{Zr} / \mathrm{Nb}$ ratios the metapicrites more likely represent slightly enriched primary melts from a convective mantle source, more specifically from garnet lherzolite. The REE patterns of the basaltic rocks are similar to those of the picritic rocks, indicating fractional crystallization of the basaltic melt from a picritic one.

On the basis the existence of two distinct rock types, stratigraphy, and minor and trace element geochemistry, the following evolution is suggested for the Salittu metavolcanic rocks: primary picritic melt from slightly enriched convective mantle source rose to the crust to form a sill-like magma chamber; fractionation in the chamber led to the development of basaltic melt; this melt extruded upon an earlier formed volcanic pile as basalt and synvolcanic gabbroic bodies; and finally picritic melts, similar in composition to the earlier picrite, rose through the crust and extruded on top of the basalt.

Comparison with modern basalts suggests that the metabasaltic rocks of Salittu were generated in an arc environment, and considering the evolved character of the earlier extruded volcanic rocks, a mature arc is most plausible. Rifting in 
the arc caused eruption of basaltic and picritic lavas. Comparison with three other metapicrite occurrences in southern Finland suggests that although the occurrences may be considered broadly comagmatic, each had their specific sources and probably also tectonic environments during emplacement.

\section{References}

Barnes, S.J., Makkonen, H.V., Dowling, S.E., Hill, R.E.T. \& Peltonen,P., 2009. The 1.88 Ga Kotalahti and Vammala nickel belts, Finland: geochemistry of the mafic and ultramafic metavolcanic rocks. Bulletin of the Geological Society of Finland 81, 103-141.

Berge, J., 2013. Likely "mantle plume" activity in the Skellefte district, Northern Sweden. A reexamination of mafic/ ultramafic magmatic activity: Its possible association with VMS and gold mineralization. Ore Geology Reviews 55, 64-79.

https://doi.org/10.1016/j.oregeorev.2013.04.008

Bergström, U., 1997. Marginal basin magmatism in an ancient volcanic arc: Petrology of the Palaeoproterozoic Malagroup basalts, Skellefte District, northern Sweden. GFF 119, 151-157.

https://doi.org/10.1080/11035899709546472

Boynton, W.V., 1984. Geochemistry of the rare earth elements: meteorite studies. In: Henderson, P. (ed.), Rare Earth Element Geochemistry. Elsevier, Amsterdam, 63-114. https://doi.org/10.1016/b978-0-444-42148-7.50008-3

Eggins, S.M., 1993. Origin and differentiation of picritic arc magmas, Ambae (Aoba), Vanuatu. Contributions to Mineralogy and Petrology 114, 79-100. https://doi.org/10.1007/bf00307867

Ellam, R.M. \& Cox, K.G., 1991. An interpretation of Karoo picrate basalts in terms of interaction between asthenospheric magmas and the mantle lithosphere. Earth and Planetary Science Letters 105, 330-342. https://doi.org/10.1016/0012-821x(91)90141-4

Eskola, P., 1914. On the petrology of the Orijärvi region in southwestern Finland. Bulletin de la Commission Géologique de Finlande 40, 67-102.

Frey, F.A., Green, D.H. \& Roy, S.D., 1978. Integrated models of basalt petrogenesis: a study of quartz tholeiites to olivine melilites from south eastern Australia utilizing geochemical and experimental petrological data. Journal of Petrology 19, 463-513. https://doi.org/10.1093/petrology/19.3.463

Hanski, E.J., 1992. Petrology of Pechenga ferropicrites and cogenetic, Ni-bearing gabbro-wehrlite intrusions, Kola Peninsula, Russia. Geological Survey of Finland, Bulletin $367,192 \mathrm{p}$.

\section{Acknowledgements}

I thank Abigail Barker, Jussi Heinonen (Editor in Chief), and an anonymous reviewer for helpful comments to the manuscript, and Raimo Lahtinen and Petri Peltonen for discussions during preparation of the manuscript.

Hanski, E.J. \& Smolkin, V.F., 1995. Iron- and LREE-enriched mantle source for early Proterozoic intraplate magmatism as exemplified by the Pechenga ferropicrites, Kola Peninsula, Russia. Lithos 34, 107-125. https://doi.org/10.1016/0024-4937(94)00035-z

Hanski, E., Huhma, H., Smolkin, V.F. \& Vaasjoki, M., 1990. The age of the ferropicritic volcanics and comagmatic $\mathrm{Ni}$ bearing intrusions at Petchenga, Kola Peninsula, U.S.S.R. Bulletin of the Geological Society of Finland 62, 123-133.

Hanski, E., Huhma, H., Rastas, P. \& Kamenetsky, V.S., 2001. The Paleoproterozoic komatiite-picrite association of Finnish Lapland. Journal of Petrology 42, 855-876. https://doi.org/10.1093/petrology/42.5.855

Hart, S.R. \& Davis, K.E., 1978. Nickel partitioning between olivine and silicate melt. Earth and Planetary Science Letters 40, 203-219. https://doi.org/10.1016/0012-821x(78)90091-2

Heinonen, J.S. \& Luttinen, A.V., 2008. Jurassic dikes of Vestfjella, western Dronning Maud Land, Antarctica: Geochemical tracing of ferropicrite sources. Lithos 105, 347-364. https://doi.org/10.1016/j.lithos.2008.05.010

Herzberg, C. \& O’Hara, M.J., 1998. Phase equilibrium constraints on the origin of basalts, picrites, and komatiites. Earth-Science Reviews 44, 39-79. https://doi.org/10.1016/s0012-8252(98)00021-x

Ireland, T.J., Walker, R.J. \& Garcia, M.O., 2009. Highly siderophile element and 187 Os systematics of Hawaiian picrites: Implications for parental melt composition and source heterogeneity. Chemical Geology 260, 112-128 https://doi.org/10.1016/j.chemgeo.2008.12.009.

Jennings, E.S., Gibson, S.A., Maclennan, J. \& Heinonen, J., 2017. Deep mixing of mantle melts beneath continental flood basalt provinces: Constraints from olivine-hosted melt inclusions in primitive magmas. Geochimica et Cosmochimica Acta 196, 36-57. https://doi.org/10.1016/j.gca.2016.09.015

Klewin, K.W. \& Shirley, S.B., 1992. The igneous petrology and magmatic evolution of the Midcontinent rift system. Tectonophysics 213, 33-40. https://doi.org/10.1016/0040-1951(92)90249-6

Kousa, J., 1985. Rantasalmen tholeiittisista ja komatiittisista vulkaniiteista. Summary: The tholeiitic and komatiitic 
metavolcanics in Rantasalmi, Southeastern Finland. Geologi 37, 18-22.

Lahtinen, R., Korja, A. \& Nironen, M., 2005. Paleoproterozoic tectonic evolution. In: Lehtinen, M., Nurmi, P.A., Rämö, O.T. (eds.) Precambrian Geology of Finland - Key to the Evolution of the Fennoscandian Shield. Elsevier B.V., Amsterdam, 481-532. https://doi.org/10.1016/s0166-2635(05)80012-x

Larsen, L.M., Pedersen, A.K., Sundvoll, B. \& Frei, R., 2003. Alkali picrites formed by melting of old metasomatized lithosphere mantle: Manitdlat Member, Vaigat Formation, Paleogene of West Greenland. Journal of Petrology 44, 3-38. https://doi.org/10.1093/petrology/44.1.3

Le Bas, M.J., 2000. IUGS reclassification of the high- $\mathrm{MgO}$ and picritic volcanic rocks. Journal of Petrology 41, 14671470 . https://doi.org/10.1093/petrology/41.10.1467

Li, C., Arndt, N.T., Tang, Q. \& Ripley, E.M., 2015. Trace element indiscrimination diagrams. Lithos 232, 76-83. https://doi.org/10.1016/j.lithos.2015.06.022

Lightfoot, P.C., Hawkesworth, C.J., Hergt, J., Naldrett, A.J., Gorbachev, N.S., Fedorenko, V.A. \& Doherty, W., 1993. Remobilisation of the continental lithosphere by a mantle plume: major-, trace-element, and $\mathrm{Sr}-$, $\mathrm{Nd}-$, and $\mathrm{Pb}-$ isotope evidence from picritic and tholeiitic lavas of the Noril'sk District, Siberian Trap, Russia. Contributions to Mineralogy and Petrology 114, 171-188. https://doi.org/10.1007/bf00307754

Makkonen, H., 1996. 1.9 Ga tholeiitic magmatism and related $\mathrm{Ni}-\mathrm{Cu}$ deposition in the Juva area, SE Finland. Geological Survey of Finland, Bulletin 386, 101 p.

Mann, P., Taylor, F.W., Lagoe, M.B., Quarles, A. \& Burr G., 1998. Accelerating late Quaternary uplift of the New Georgia Island Group (Solomon island arc) in response to subduction of the recently active Woodlark spreading center and Coleman seamount. Tectonophysics 295, 259-306. https://doi.org/10.1016/s0040-1951(98)00129-2

Mantle, G.W. \& Collins, W.J., 2008. Quantifying crustal thickness in evolving orogens: Correlation between arc basalt composition and Moho depth. Geology 36, 87-90. https://doi.org/10.1130/G24095A.

McDonough, W.F. \& Sun, S.-s., 1995. The composition of the Earth. Chemical Geology 120, 223-253. https://doi.org/10.1017/cbo9780511812910.003

Melluso, L., Mahoney, J.J. \& Dallai, L., 2006. Mantle sources and crustal input as recorded in high-Mg Deccan Traps basalts of Gujarat (India). Lithos 89, 259-274. https://doi.org/10.1016/j.lithos.2005.12.007

Mikkola, T., 1950. Origin of ultrabasics in the Orijärvi region. Bulletin de la Commission Géologique de Finlande 168, 39-52.
Mungall, J.E., 2007. Crustal contamination of picritic magmas during transport through dikes: the Expo Intrusive Suite, Cape Smith Fold Belt, New Quebec. Journal of Petrology 48, 1021-1039. https://doi.org/10.1093/petrology/egm009

Nironen, M., Mänttäri, I. \& Väisänen, M., 2016. The Salittu Formation in southwestern Finland I: Structure, age and stratigraphy. Bulletin of the Geological Society of Finland 88, 85-103. https://doi.org/10.17741/bgsf/88.2.003

Pearce, J.A., 1983. Role of the sub-continental lithosphere in magma genesis at active continental margins. In: Hawkwsworth, C.J., Norry, M.J. (eds.) Continental Basalts and Mantle Xenoliths. Nantwich, Shiva, 230-249.

Pearce, J.A. \& Norry, M.J., 1979. Petrogenetic implications of $\mathrm{Ti}, \mathrm{Zr}, \mathrm{Y}$, and $\mathrm{Nb}$ variations in volcanic rocks. Contributions to Mineralogy and Petrology 69, 33-47. https://doi.org/10.1007/bf00375192

Peltonen, P., 1995. Petrogenesis of ultramafic rocks in the Vammala Nickel Belt: Implications for magmatism and crustal evolution of the early Proterozoic Svecofennian arc terrane. Lithos 34, 253-274. https://doi.org/10.1016/0024-4937(94)00042-z

Peltonen, P., Kontinen, A. \& Huhma, H., 1996. Petrology and geochemistry of metabasalts from the $1.95 \mathrm{Ga}$ Jormua Ophiolite, northeastern Finland. Journal of Petrology 37, 1359-1383. https://doi.org/10.1093/petrology/37.6.1359

Rasilainen, K., Lahtinen, R. \& Bornhorst, T.J. 2007. The Rock Geochemical Database of Finland Manual. Geological Survey of Finland, Report of Investigation 164, 38 p.

Rohrbach, A., Schuth, S., Ballhaus, C., Münker, C., Matveev, S. \& Qopoto, C. 2005. Petrological constraints on the origin of arc picrites, New Georgia Group, Solomon Islands. Contributions to Mineralogy and Petrology 149, 685-698. https://doi.org/10.1007/s00410-005-0675-6

Salli, I., 1955. Suomusjärvi. Geological map of Finland 1:100 000, pre-Quaternary rocks, sheet 2023, Geological Survey of Finland.

Schreurs, J. \& Westra, L,. 1986. The thermotectonic evolution of a Proterozoic, low pressure, granulite dome, West Uusimaa, SW Finland. Contributions to Mineralogy and Petrology 93, 236-250. https://doi.org/10.1007/ BF00371326

Schreurs, J., van Kooperen, P. \& Westra, L., 1986. Ultramafic metavolcanic rocks of early proterozoic age in WestUusimaa, SW Finland. Neues Jahrbuch für Mineralogie -Abhandlungen 155, 185-201.

Schuth, S., Rohrbach, A., Münkler, C., Ballhaus, C., GarbeSchönberg, D. \& Qopoto, C., 2004. Geochemical constraints on the petrogenesis of arc picrites and basalts, New Georgia Group, Solomon Islands. Contributions to Mineralogy and Petrology 148, 288-304. https://doi.org/10.1007/s00410-004-0604-0 
Sharkov, E.V. \& Bogina, M.M. 2009. Mafic-ultramafic magmatism of the early Precambrian (from the Archean to Paleoproterozoic). Stratigraphy and Geological Correlation 17, 117-136. https://doi.org/10.1134/S0869593809020026

Skyttä, P. \& Mänttäri, I., 2008. Structural setting of late Svecofennian granites and pegmatites in Uusimaa belt, SW Finland: Age constraints and implications for crustal evolution. Precambrian Research 164, 86-109. https://doi.org/10.1016/j.precamres.2008.04.001

Sorbadere, F., Schiano, P., Métrich, N. \& Garaebiti, E., 2011. Insights into the origin of primitive silicaundersaturated arc magmas of Aoba volcano (Vanuatu arc). Contributions to Mineralogy and Petrology 162, 995-1009. https://doi.org/10.1007/s00410-011-0636-1

Sun, S.S. \& McDonough, W.F., 1989. Chemical and isotopic systematic of oceanic basalts: implications for mantle compositions and processes. In: Saunders, A.D., Norry, M.J. (Eds.) Magmatism in the Ocean Basins. Geological Society, London, Special Publications 42, 313-345. https://doi.org/10.1144/gsl.sp.1989.042.01.19

Sutcliffe, R.H. 1987. Petrology of middle Proterozoic diabases and picrites from Lake Nipigon, Canada. Contributions to Mineralogy and Petrology 96, 201-211. https://doi.org/10.1007/bf00375234

Tsikouras, B., Pe-Piper, G., Piper, D.J.W. \& Hatzipanagiotou, K., 2008. Triassic rift-related komatiite, picrite and basalt, Pelagonian continental margin, Greece. Lithos 104, 199215. https://doi.org/10.1016/j.lithos.2007.12.007

Väisänen, M., Mänttäri, I., 2002. 1.90-1.88 Ga arc and backarc basin in the Orijärvi area, SW Finland. Bulletin of the Geological Society of Finland 74, 185-214.
Verma, S.P. 2006. Extension-related origin of magmas from a garnet-bearing source in the Los Tuxtlas volcanic field, Mexico. International Journal of Earth Sciences 95, 871901. https://doi.org/10.1007/s00531-006-0072-z

Wilson, M., 1989. Igneous petrogenesis - a Global Tectonic Approach. Unwin Hyman, London, 466 p.

Woodland, S.J., Pearson, D.G. \& Thirlwall, M.F., 2002. A platinum group element and $\mathrm{Re}-\mathrm{O}$ s isotope investigation of siderophile element recycling in subduction zones: comparison of Grenada, Lesser Antilles Arc, and the IzuBonin Arc. Journal of Petrology 43, 171-198. https://doi.org/10.1093/petrology/43.1.171

Zhang, Z., Mahoney, J.J., Mao, J. \& Wang, F., 2006. Geochemistry of picritic and associated basalt flows of the Western Emeishan flood basalt province, China. Journal of Petrology 47, 1997-2019. https://doi.org/10.1093/petrology/egl034

Zhang, Z., Mao, J., Cai, J., Kusky, T.M., Zhou, G., Yan, S. \& Zhao, L., 2008. Geochemistry of picrites and associated lavas of a Devonian island arc in the northern Junggar terrane, Xinjiang (NW China): Implications for petrogenesis, arc mantle sources and tectonic setting. Lithos 105, 379-395. https://doi.org/10.1016/j.lithos.2008.05.013

Yamamoto, M., 1988. Picritic primary magma and its source mantle for Oshima-Ōshima and back-arc side volcanoes, Northeast Japan arc. Contributions to Mineralogy and Petrology 99, 352-359. https://doi.org/10.1007/bf00375367 